\title{
SOME BIOCHEMICAL PROPERTIES OF BACILLUS LARVAE WHITE
}

\author{
Marian JELIǸSKI \\ Department for Research of Useful Insect Diseases Swarzędz of Veterinary Institute Putawy \\ ul. Poznańska 35, Pl 62-020 Swarzȩdz Poland
}

\begin{abstract}
SUMMARY
The biochemical properties of 110 strains of Bacillus larvae were determined. All strains produced lipases and proteases on the test media, but varied widely in the time of appearance of the former. Only fifty-nine percent of the strains reduced nitrate to nitrite. All strains metabolized glucose, trehalose and glycerol with production of acid, and produced hydrogen sulphide from added cysteine-HCl. All strains lacked catalase and amylase. Variations between strains in reduction of nitrate to nitrite, hydrolysis of mannitol, and production of acid from salicin, permit one to distinguish 7 biochemical types of $B$. larvae.
\end{abstract}

\section{INTRODUCTION}

The biochemical properties of $B$. larvae have been examined by other workers using a small number of strains for their investigations. The organism reduces nitrate to nitrite (BITNER, 1971), but not all strains share this property (HitchCOCK and Wilson, 1973 ; Gibson and Gordon, 1974 ; DrobníkOVÁ, 1978). B. larvae grows well aerobically, but lacks catalase (HAYNES, 1972 ; Gibson and Gordon, 1974 ; DrobníkOVA, 1978). The organism produces $\mathrm{H}_{2} \mathrm{~S}$ and ferments glucose (AZUMA and KITAOKA, 1965). The latter authors also showed that presence of glucose in the growth medium inhibits the normal production of proteolytic enzymes. The lipolytic activity of $B$. larvae is high in media with Tween 40 and Tween 60 as substrate (JELIŃSKI, KOSTECKI and S kUŻEWSKA, 1976).

Some reports on the biochemical properties of $B$. larvae are in disagreement with each other. Therefore, I examined the activity of 110 strains on the above substrates. I determined the time required for manifestation of the proteolytic and lipolytic activity of the strains, the reduction of nitrate to nitrite and the aerobic production of acid from glucose, trehalose, glycerol, mannitol and salicin. In addition, I examined starch hydrolysis and the production of hydrogen sulphide from cysteine- $\mathrm{HCl}$. 


\section{MATERIALS AND METHODS}

\section{The cultures}

B. larvae strains NRRL B-2605, NRRL B-2610, NRRL B-3554, NRRL B-3558, NRRL B-3650 (see GordoN, HAYNES and PANG, 1973 for their descriptions), NRRL B-4193, NRRL B-4194 and NRRL B-4195 were received from the culture collection of the Northern Regional Research Laboratories, USDA, Peoria, Illinois, U.S.A. ; other cultures were obtained from Poland (94), Bulgaria (5), U.S.A. (2) and Sweden (1 isolate). Altogether 110 strains were examined. These were maintained on Willis and Hobbs medium slants (ZAHACZEWSKI and KoMOROWSK1, 1972), modified by JelińskI, KosTECKI and ZAHACZEWSKI (1975) (modified W.H. medium). The modified W.H. medium was of the following composition :

Part A : $40 \mathrm{~cm}^{3}$ of egg yolk emulsion with cow's milk, which was made from $180 \mathrm{~cm}^{3}$ milk and 3 chicken's egg yolks. The fresh farm milk was boiled and after cooling skin the which was formed was picked out. It was sterilized at $117^{\circ} \mathrm{C}$ for $20 \mathrm{~min}$. in conical flask with crystal beads. After cooling the egg yolks were poured. The flask was shaken vigorously by hand and an emulsion was made.

Part B : $200 \mathrm{~cm}^{3}$ of basal medium with $2 \%$ agar (pH 7,4). When the temperature of this part has fallen to $60{ }^{\circ} \mathrm{C}, 40 \mathrm{~cm}^{3}$ of warm egg yolk emulsion with milk was added. The emulsion can be frozen $\left(-15{ }^{\circ} \mathrm{C}\right)$ and stored, but before use it should be dissolved by heating. At a temperature of ca $40^{\circ} \mathrm{C}$ part $\mathrm{A}$ was added. Then the contents were gently poured into Petri dishes or culture tubes.

The growth from the slant was transferred to a plate with modified W.H. medium and incubated for 3-5 days until used in the biochemical tests.

\section{Biochemical tests}

Plates with appropriate media were inoculated with a streak of culture and subjected to the following tests.

- Starch hydrolysis : the modified W.H. medium was used, but to part B was added $1 \%$ soluble starch. The starch was dissolved separately in double distilled water in a water bath and added to the basal medium. The small plates $(5 \mathrm{~cm}$ diameter) were used (JeLINSKI, 1978). After an inoculation in the center of the medium they were placed in a large Petri dish $(19 \mathrm{~cm}$ diameter). Lugol's solution was poured on the 7 days' cultures.

- Proteolysis : as above. Observations for proteolytic activity were made on the 2 nd and 3 rd day. The proteinase-producing organism should be surrounded by a lighter zone usually extending several mm from a colony.

- Lipolysis : as above, but the modified W.H. medium without starch was used. The plates were observed daily from the 3 rd to the 7 th day or longer, as required.

- Catalase : a solution of $3 \%$ hydrogen peroxide was sprinkled over the streak of growth and examined for formation of gas bubbles (JELIŃSKI, 1978).

- Acid production from carbohydrates : this was examined in a medium of the following composition, in $\mathrm{g}$ per liter of medium :

$10 \mathrm{~g}$ soluble starch,

10 g yeast extract (GURR),

$20 \mathrm{~g}$ agar,

$0.008 \mathrm{~g}$ bromocresol purple,

1 liter double distilled water.

To the above was added one of the following :

$5 \mathrm{~g} \mathrm{D}(+)$-glucose,

trehalose,

glycerol,

D-mannitol,

salicin. 
The medium was adjusted to the formation of the purple colour with the addition of a $2 \%$ solution of $\mathrm{KOH}$ and autoclaved at $117^{\circ} \mathrm{C}$ for $15 \mathrm{~min}$. After autoclaving, the medium was added aseptically to sterile culture tubes, $15 \times 100 \mathrm{~mm}$, and allowed to cool and solidify on a slant. After inoculation of the surface with a streak of the culture being tested, the tubes were incubated at $35^{\circ} \mathrm{C}$ and observed at $2-5$ days for production of acid.

Hydrogen sulphide production : biphasic cultures were prepared as follows. A base layer of modified W.H. medium was prepared as a slant in a tube. A physiological buffered saline solution : $\mathrm{NaCl} 8 \mathrm{~g}, \mathrm{KCl} 0.2 \mathrm{~g}$, $\mathrm{CaCl}_{2} 0.1 \mathrm{~g}, \mathrm{Na}_{2} \mathrm{HPO}_{4} 1.15 \mathrm{~g}, \mathrm{KH}_{2} \mathrm{PO}_{4} 0.2 \mathrm{~g}, \mathrm{MgCl}_{2} \cdot 6 \mathrm{H}_{2} \mathrm{O} 0.1 \mathrm{~g}$, double distilled water 1 liter; $\mathrm{pH} 7,4 ;$ molarity 300 mOsm produced by Wytwórnia Surowic i Szczepionek in Lublin containing $0.02 \%$ (w/v) DL-cysteine$\mathrm{HCl}$ was autoclaved at $117^{\circ} \mathrm{C}$ for $15 \mathrm{~min}$, allowed to cool and added aseptically to cover the slant. After the liquid layer was inoculated, sterile lead acetate strips were placed aseptically under the cotton plugs. The strips were observed for darkening after 2 days.

Nitrate reduction : Broth medium was prepared as follows in $\mathrm{g}$ per liter medium :

$10 \mathrm{~g}$ yeast extract (GURR),

$10 \mathrm{~g}$ soluble starch,

$0,1 \mathrm{~g} \mathrm{KNO}_{3}$,

$0,4 \mathrm{~g} \mathrm{CaCl}_{2}$,

1 liter double distilled water.

The broth was autoclaved in $100 \mathrm{ml}$ lots at $117^{\circ} \mathrm{C}$ for $15 \mathrm{~min}$ and added aseptically to sterile tubes. After 5 days incubation, presence of nitrite was detected with Griss's reagents (SOCIETY OF AMERICAN BACTERIOLOGISTS, 1957).

\section{RESULTS AND DISCUSSION}

All strains of $B$. larvae were catalase negative when grown on modified W.H. medium (Table 1). Haynes (1972) and Drobniková (1978) reported the same results, and indicated that Bacillus alvei, in contrast, was catalase positive. Gordon, Haynes and PANg (1973), Gibson and Gordon (1974) and JelińsKi (1978) also reported B. larvae as catalase negative. Most Bacillus spp. are recorded as catalase positive (GORDON, HAYNES and PANG, 1973).

TABL. 1 - Biochemical properties of the strains of $\mathrm{B}$. larvae reported here

\begin{tabular}{|c|c|c|c|c|c|c|c|c|c|}
\hline \multirow[b]{2}{*}{ 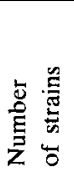 } & \multirow[b]{2}{*}{$\frac{\mathscr{g}}{\stackrel{g}{\Xi}}$} & \multirow[b]{2}{*}{$\frac{\mathscr{S}}{\mathbb{E}}$} & \multirow[b]{2}{*}{$\stackrel{n}{I^{\prime}}$} & \multirow{2}{*}{ 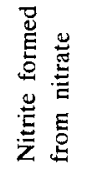 } & \multicolumn{5}{|c|}{ Production of acid from } \\
\hline & & & & & $\frac{\mathscr{D}}{\mathscr{8}}$ & 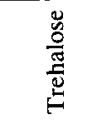 & $\begin{array}{l}\overline{0} \\
\frac{2}{2} \\
\frac{2}{0}\end{array}$ & $\frac{\bar{\Xi}}{\stackrel{\Xi}{\Xi}}$ & 㞼 \\
\hline 110 & $0 / 110^{(1)}$ & $0 / 110$ & $110 / 110$ & $64 / 110$ & $110 / 110$ & $110 / 110$ & $109 / 110$ & $19 / 110$ & $12 / 110$ \\
\hline
\end{tabular}

(1) Number of strains which showed a positive reaction/number of investigated strains.

None of the strains hydrolyzed starch incorporated into the modified W.H. medium, in agreement with previous reports (AZUMA and KITAOKA, 1965; 
Gordon, Haynes and PANG, 1973 ; Gibson and Gordon, 1974 ; Jeliński, 1978). Variable results were obtained in the nitrate reduction tests : only 64 of 110 reduced nitrate in the present tests. The strain NRRL B-3650, reported negative by previous workers (HAYNES, 1972; GORDON, HAYNES and PANG, 1973 ; HITCHCOCK and WILSON, 1973) was negative in our tests also. AzUMA and КIтAOKA (1965) reported their cultures reduced nitrate both in nitrate broth and in modified H.S. medium (Table 3). However, results obtained by other workers (HAYNES, 1972 ; GORdON, HAYNES and PANG, 1973 ; HitchCOCK and Wilson, 1973 ; DrobNíKOVA, 1978) show that reactions on nitrate among different strains of $B$. larvae are variable.

All strains tested released hydrogen sulphide from DL-cysteine- $\mathrm{HCl}$ in the above described medium. AzUMA and KITAOKa (1965) reported that B. larvae produced $\mathrm{H}_{2} \mathrm{~S}$ as did GochNaUer and MARGeTtS (1982). According to ZAHACZEWSKA and FUROWICZ (1964), MIKA (1968), and FUROWICZ and ZAHACZEWSKA (1972), this organism does not produce $\mathrm{H}_{2} \mathrm{~S}$. In this work, I observed that it is desirable to add the DL-cysteine- $\mathrm{HCl}$ to the tube about one week or more before inoculation. A fresh medium can give misleading results.

Metabolism of glucose was typical for all strains studied. This observation agrees with results of previous workers (GORDON, HAYNES and PANG, 1973) who reported production of acid from this sugar. ZAHACZEWSKA and FurowiCZ (1964), AzUMA and Kitaoka (1965), Mika (1968) and FurowicZ and ZAHACZEWSKA (1972) observed fermentation of glucose which is a uniform characteristic for $B$. larvae.

Bacillus larvae hydrolyzed trehalose. All strains were positive for this reaction, in agreement with reports of Gordon, HAYNES and PANG (1973), and FUROWICZ and ZAHACZEWSKA (1972).

All but one strain hydrolyzed glycerol. MIKA (1968) recorded variable results with this substrate.

Relatively few strains attacked mannitol. MiKa (1968) and Furowicz and ZAHACZEWSKA (1972) reported that B. larvae fermented mannitol. According to AZUMA and KitAoKA (1965) all strains were negative for this reaction (Table 3). My results were in agreement with those of GORDON, HAYNES and PANG (1973).

Even fewer strains hydrolyzed salicin. These results differed somewhat from those of other workers. MIKA (1968) reported that all strains attacked this glycoside. According to Azuma and Kitaoka (1965) $B$. larvae fermented salicin, but some strains were positive for this reaction after 9 days of incubation (Table 3).

The proteolytic activity of the strains was evident on casein, added as cows milk to the modified W.H. medium (Table 2). Caseinase activity appeared as 
TABL. 2 - Time course of appearance of proteolytic and lipolytic activity of strains of B. larvae on modified W.H. medium

\begin{tabular}{|c|c|c|c|c|c|c|c|c|c|}
\hline \multirow{2}{*}{ 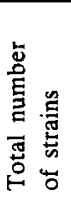 } & \multicolumn{2}{|c|}{ 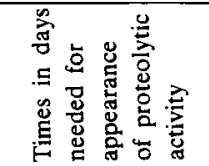 } & \multicolumn{7}{|c|}{$\begin{array}{c}\text { Time in days needed for appearance } \\
\text { of lipolytic activity }\end{array}$} \\
\hline & 2 & 3 & 3 & 4 & 5 & 6 & 7 & 8 & 10 \\
\hline 110 & 75 (1) & $\begin{array}{c}35 \\
(110)^{(2)}\end{array}$ & 16 & $\begin{array}{c}24 \\
(40)\end{array}$ & $\begin{array}{c}33 \\
(73)\end{array}$ & $\begin{array}{c}16 \\
(89)\end{array}$ & $\begin{array}{c}19 \\
(108)\end{array}$ & $\begin{array}{c}1 \\
(109)\end{array}$ & $\begin{array}{c}1 \\
(110)\end{array}$ \\
\hline
\end{tabular}

(1) Number of strains which first showed a positive reaction on a given day.

(2) Numbers in parenthesis are the cumulative totals of strains showing a positive reaction.

a clear zone near the growth by the second day of incubation. Azuma and KITAOKA (1965) have reported the hydrolysis of casein by $B$. larvae.

Lipase activity of the strains was demonstrated on egg yolk added to the modified W.H. medium. Previous determinations of this property have been made by JelińsKi, KosteCKI and ZAHACZEWSKI (1975) and JeliŃSKI, KosTECKI

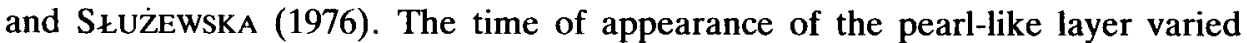
from 3 to 10 days, with the greatest number occurring at 5 days. All strains were positive by 10 days. A plot of the cumulative numbers of positive cultures against time in days shows an almost linear increase up to 5 days with an estimated time of 4.5 days to reach $50 \%$ of the cultures with positive reactions.

The present investigations revealed that consistent features of $B$. larvae include : presence of proteolytic and lipolytic activity, the production of hydrogen sulphide from $\mathrm{DL}$-cysteine- $\mathrm{HCl}$, the lack of catalase and amylase activity, and production of acid from trehalose, glucose and glycerol. The methods described can be helpful in distinguishing among biochemical types of $B$. larvae and their relative occurrence in disease outbreaks. Thus the variable features described here, including mannitol hydrolysis, production of acid from salicin and nitrate reduction, can be important (Table 3 ).

It is interesting that strain NRRL B-3558 produces acid from mannitol, although GoRdon, HAYNES and PANG (1973) recorded negative results for the strain. On the basis of the positive reaction, I have included it in biochemical type VII (Table 3). The strain NRRL B-2605 does not split mannitol, although it was recorded as positive by Gordon, HAYNes and PANG (1973). It may be of interest to determine the reason for these discrepancies. The biochemical type VIII (Table 3) is one for which no strains are known. 


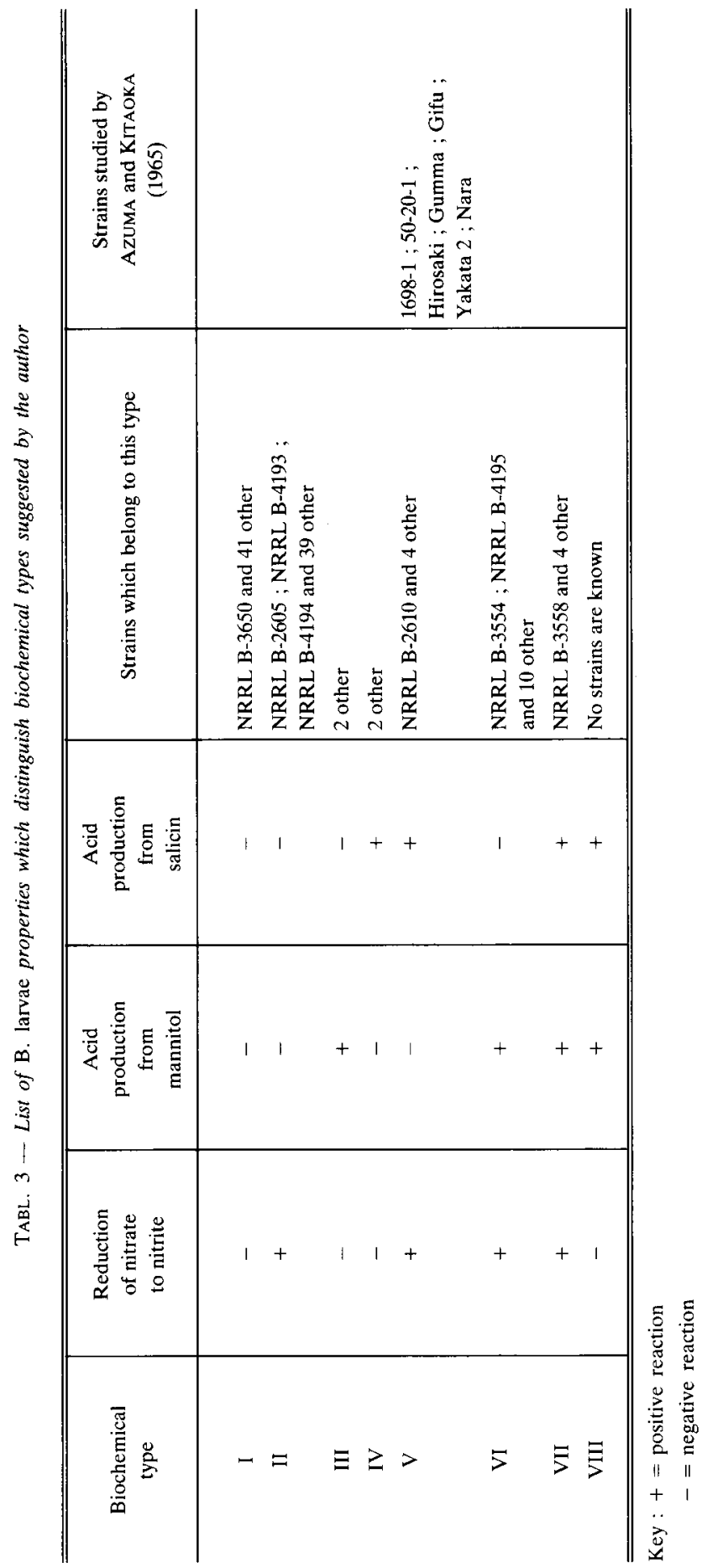




\title{
ACKNOWLEDGEMENTS
}

I wish to thank Mr. Holmberg from Sweden, Miss Menapace and Dr NaKamura from the U.S.A., and Dr Shabanov from Bulgaria for their help. Dr Gochnauer provided some of the standard strains used and assistance with the English text.

\author{
RESUMÉ \\ QUELQUES PROPRIÉTÉS BIOCHIMIQUES DE BACILLUS LARVAE WHITE
}

On a déterminé les propriétés biochimiques de 110 souches de Bacillus larvae - agent étiologique de la loque américaine chez l'abeille domestique. Les souches ont été cultivées en tube sur le milieu de Willis et Hobbs modifié. Les recherches, faites sur des plaques d'un milieu approprié, ont porté sur l'hydrolyse de l'amidon, la protéolyse, la lipolyse et la catalase. Dans un autre test on a déterminé la production d'acide à partir de certains glucides. Pour ces tests on a utilisé des cultures en tube sur milieu gélosé de composition suivante : amidon soluble (1\%), extrait de levure $(1 \%)$, pourpre de bromocresol $\left(8 \times 10^{-1} \%\right)$ et agar $(2 \%)$. A cela on a ajouté $0,5 \%$ de glucide. On a préparé des cultures biphasiques pour l'étude de la production d'hydrogène sulfuré. Pour la réduction des nitrates un milieu de culture de la composition suivante a été utilisé : extrait de levure $(1 \%)$, amidon soluble $(1 \%), \mathrm{KNO}_{3}(0,01 \%)$ et $\mathrm{CaCl}_{2}(0,04 \%)$.

On a pu établir que toutes les souches produisaient des lipases et des protéases sur les milieux testés, mais que le délai d'apparition des premières variait fortement. Seulement $51 \%$ des souches ont réduit les nitrates en nitrites. Toutes les souches ont métabolisé le glucose, le tréhalose et le glycérol avec production d'acide et ont produit de l'hydrogène sulfuré à partir du mélange cystéine- $\mathrm{HCl}$ ajouté. La catalase et l'amylase sont absentes de toutes les souches. Des variations entre les souches concernant la réduction des nitrates en nitrites, l'hydrolyse du mannitol et la production d'acide à partir de salicine ont permis de distinguer au moins 7 types biochimiques de Bacillus larvae.

\section{ZUSAMMENFASSUNG}

\section{EINIGE BIOCHEMISCHE EIGENSCHAFTEN VON BACILLUS LARVAE WHITE}

Es wurden die biochemischen Eigenschaften von 110 Stämmen von Bacillus larvae - dem Erreger der bösartigen Faulbrut der Honigbiene - untersucht. Die Stämme wurden in dem modifizierten Medium nach Willis und Hobbs gehalten. Die Untersuchung erfolgte auf Petrischalen mit geeigneten Medien für Stärke-Hydrolyse, Proteolyse, Lipolyse und Katalase. In einem anderen Test wurde die Säurebildung aus Kohlenhydraten bestimmt. Dazu wurden Nährlösungen von folgender Zusammensetzung benutzt : Lösliche Stärke, Hefe-Extrakt, Bromkresol-Purpur, Agar und Wasser. Es wurden 0,5\% Kohlenhydrate hinzugefügt. Für die Untersuchung der Bildung von Schwefelwasserstoff wurden biphasische Kulturen hergestellt. Für die Nitratreduktion wurde eine Nährlösung folgender Zusammensetzung benutzt : Hefe-Extrakt, lösliche Stärke, $\mathrm{KNO}_{3}, \mathrm{CaCl}_{2}$ und Wasser.

Auf diese Weise wurde festgestellt, daß alle Stämme Lipasen und Proteasen in den Testmedien erzeugten, daß aber der Zeitpunkt des Auftretens der ersteren stark schwankte. Nur 59 Prozent der Stämme reduzierten Nitrat zu Nitrit. Alle Stämme metabolisierten Glukose, Trehalose und Glyzerol unter Säurebildung und sie erzeugten Schwefelwasserstoff aus hinzugefügtem Cystein. Allen Stämmen fehlten Katalase und Amylase. Unterschiede zwischen den Stämmen in der Reduktion von Nitrat zu Nitrit, der Hydrolyse von Mannitol und der Säurebildung aus Salicin gestatten die Unterscheidung von 7 biochemischen Typen von B. larvae. 


\section{REFERENCES}

Azuma R., Kitaoka S., 1965. - Cultivation and properties of Bacillus larvae and dectease of its proteolytic activity on glucose media. Nat. Inst. Anim. Hlth Quart., 5, 138-145.

Brtner A.R., 1971. - Nitrite test as an aid in the identification of Bacillus larvae grown in yeast-starch agar. Am. Bee J., 111, 385, 391.

Drobnikova V., 1978 - Diagnostika Bacillus larvae - puvodce moru včelího plodu. Vererinárni Medicína, 23, 185-191.

Furowicz A.J., Zahaczewska M., 1972. - Biochemische Untersuchungen zur Bestimmung der Empfindlichkeit von Stämmen der Bac. larvae White gegenüber Antibiotika, p. 476. In : "Der XXIII. Int. Bienenzüchterkongress Moskau 1971 ». Bukarest, Rumänien : Apimondia Verlag.

GiBSON T., GORDON R.E., 1974. - Endospore-forming rods and cocci, Part 15, pp. 529-575. In: * Bergey's Manual of Determinative Bacteriology *. 8th ed. R.E. Buchanan and N.E. Gibbons, Eds. Williams and Wilkins Co., Baltimore.

Gordon R.E., Haynes W.C., Pang C.H.N., 1973. - «The genus Bacillus ». Handb. Agric. U.S. Dep. Agric. No. 427.

Gochnauer T.A., MargetTs V.J., 1982. - Production of hydrogen sulphide by Bacillus larvae in vitro. J. apic. Res., 21, 161-164.

HAYnes W.C., 1972. - The catalase test. An aid in the identification of Bacillus larvae. Am. Bee J., 112, 130-131.

HITChCOCK J.D., Wilson W.T., 1973. - Pathogenicity to honey bees of a strain of Bacillus larvae that does not reduce nitrate. J. econ. Ent., 66, 901-902.

Jelinśkı M., Kosteckı R., ZAHAczewskı J., 1975. - Abgeänderter Willis-Hobbs-Nährboden für Bacillus larvae Kulturen, pp. 400-402. In : "Der XXV. Int. Bienenzüchterkongress der Apimondia Grenoble 1975 ». Bukarest, Rumänien : Apimondia Verlag.

Jelı́ńskı M., Kosteckı R., Slużewska M., 1976. - Aktywność lipolityczna Bacillus larvae White. Medycyna Weterynaryjina, 32, 600-602.

JelińsKi M., 1978. - Niektóre wl aściwości biochemiczne Bacillus larvae White, vol. I, p. 209. In : «P.T.N.W. Biuletyn VI Zjazdu Wroclaw 21-23 września 1978r». Wroclaw.

MIKA J., 1968. - Badania nad wl aściwościami szczepów laseczki larwy (Bacillus larvae White) wystȩpujących na terenie woj. opolskiego. Medycyna Weterynaryjna, 24, 409-412.

SOCIETY OF AMERICAN BACTERIOLOGISTS, 1957. - Manual of Microbiological Methods. McGraw-Hill Book Co., New York, N.Y.

Zahaczewska M., Furowicz A., 1964. - Próba biochemicznej identyfikacji lasecznika larwy (Bacillus larvae White) przy zgnilcu zlośliwym (histolysis infectiosa perniciosa larvae). Medycyna Weterynaryjna, 20, 730-733.

ZahaczewSKı J., Komorowski A., 1972. - Usprawnienie sporządzania podtoia Willisa-Hobbs do hodowli drobnoustrojów beztlenowych. Medycyna Weterynaryjna, 28, 84-85. 